\title{
若手研究者参加への 環境整備が必要
}

国際政治心理学会（第24回年次大会）に参加して

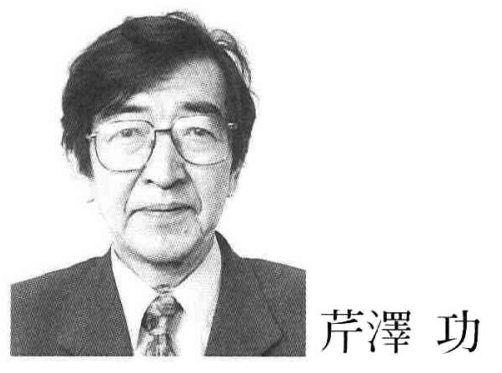

国

\section{$\checkmark \quad$ 㣰}

$\checkmark$ 源

\section{国際政治心理学会 (ISPP)}

政治現象の心理学的側面の研究は20世紀の前 半から急速に進んだ。例えば、H.D.ラスウェル は、精神病理学の成果を大胆に政治学に吸収し て以来、政治学の新領域というべきか、心理学 の新領域というべきか、明らかに伝統的学問領 域とは別の複合的学問の新分野は形成されてい たが、独立した分野との認知は第二次世界大戦 後のことになる。しかし、日本ではこの分野を 政治学科や心理学科の中で独立した分野とし て、講座として独立している大学はほとんど見 当たらない。

この分野で、仮説の提唱までは容易にできて も、その検証の困難さがともなうので、日本で は、その一部の研究、例えば、政治意識や選挙 の研究の成果は成熟しつつあるのだが、計画的
大量虐殺とか処理不能紛争問題等は十分な研究 成果を、不勉強なのか、ほとんど目にしたこと がない。

ISPPは、条国学会学位の加盟の国際学会では なく、政治心理学の研究者の個人参加による国 際交流促進と研究発表の場を提供している国際 学会である。目下、日本にも各国にもこれに直 接対応する学会は存在しない。

日本選挙学会では、研究対象が重なるので、 このISPPに個人的に会員になっているものがい て、ISPPの年次大会に每回、数名が参加してき た。その他の近隣分野の学会を背景としてISPP に参加している日本の研究者も数名いる。

ISPPは、年1回アメリカとヨーロッパの都市 で開催されてきた。前回はシアトルであったが、 今回 (第 24 回大会) は、メキシコシティ南方の クエルナバカで開催された。クエルナバカは、 
ナワ語で「木々のそば」の意味で、一部は緑の 多い別荘地だが、メキシコシティと類似の佇ま いの地域もある。

\section{ISPPラテンアメリカへ}

今回、ISPPがメキシコで開催されたので、ラ テンアメリカに初めて進出した意義を学会主催 者は強調していたが、事実、中南米から多くの 研究者の参加をみた。研究報告の使用言語も英 語にスペイン語が加えられ、メキシコをはじめ、 ラテンアメリカ諸国の研究報告も必然的に多く なり、全体の3分の 1 ぐらいは、その関係で占め られることになった。

ISPPの2001年の学会は、7月15日から18日に かけての開催であるが、実はその前日14日にワ ークショップと会長レセプションがあったので 5日間に打よんだ。14日、メキシコシティから、 バスとタクシーを乗りついで、クエルナバカ郊 外にある会場のホテル、カミノ・レアル・スミヤ にたどり着いた。ここはアメリカの金持だった バーバラ・ハットンの邸宅跡で、和風趣味である ことは事前に承知していたが、建物も庭園もど こか日本的でないところが、ご愛嬌であった。

当地は雨が多いところで、野外開催予定の最 初の会長レセプションは、早速驟雨におそわれ、 急遽、屋内バーに移動して、継続した。学会期 間中も時々雨に降られて、会場間を傘をさして
移動した。どうしても、雨の和風庭園を眺める ことになるが、植え込みの樹木に風土の差を感 じた。

15日のオープニング・レセプションは、スペ イン風庭園のあるラス・マニャニータスで開催 され、バスで移動した。テキーラ、ワイン、ビ ール等飲み物を手に盛んに交流できる仕組みに なっていた。17日には、学会彰賞の夕食会が、 ミシオン・デル・ソルで開催された。ここもバ ス移動であった。これらのパーティーは大会受 け入れ団体であるメキシコ社会心理学会 （SOMEPSO）の設営によるものであった。

\section{ISPPの動向}

今大会には、289名 (うち日本人 2 名)、30以上 の国からの参加があった。主要テーマは「暴力 の文化、平和の文化」で、これに関連する大量 虐殺、処理不能紛争等の諸要因の社会的条件、 社会構造、パーソナリティ、時代展開等のパネ ルも当然設けられ、Ervin Staub会長の講演もそ こに焦点をあてるものであった。

これとは別に、法、政策、正義、メディア、 コミュニケーション、エリート、ジェンダー 等々、各国、地域別の政治心理学の研究対象と なるパネル、ラウンド・テーブルが 200 以上詰 まっていた。

選挙、立候補者、政治エリート、政治意識等 
私の研究に直接関連する分野では、開催国メキ シコ関係が地の利を得て最も多く報告された。

2000年7月のメキシコの大統領選挙が、この 国の民主化への転換点になっているというこの 国の期待が、研究報告の底流にあると思われる。 メキシコのそれ以前の政治は、経済の自由化政 策は推進されてきたが、PRIの長期にわたる一 党支配が71年続いてきた。それが、この選挙で 政権交代が実現した。選挙による政権交代その ものが、民主化の証左なのであったが、同時に 矛盾もあるようだ。

セディージョ前大統領は、権力基盤の強化の ため次期大統領候補を指名する (デダソ) 長年の 慣行を自ら放棄して、党内予備選挙を実施した り、選挙制度を改正したにもかかわらず、野党 第1党PANの推したフォックス候補が勝利した のである。

ブッシュ米大統領は就任後最初に隣国メキシ コを訪問して、アメリカとメキシコの友好関係 を内外に示した。メキシコの民主化促進への期 待の高まりを背景に、ISPPがメキシコ開催にな ったのは偶然の一致であった。

\section{今後の課題}

開催地と少なくとも選挙関係の研究報告は良 好の関係にあったようだが、これは今回のみの 現象であろう。次回、第25回のISPPの年次大会
は2002年7月16日から19日にかけて、ベルリン で開催される予定になっている。次の主要テー マは「政治、市民権、文化の言語」で、政治心 理学の一層の理論化が期待されている。

この学会の帰路ロサンゼルス空港でのチェッ クが妙に厳しかった。テロを予想する情報があ ったからだと後で分った。9月11日のワシント ン、ニューヨークでの米中枢同時テロが起こっ た。今回のISPPの企画にテロを対象とするパネ ルが、テロリズムの専門家が会員の中にいるに もかかわらずなかった。パーティーでテロの研 究者との話でも、このテロを予想するような話 はついぞ耳にすることはなかった。しかし、次 回以後、テロを対象とするパネルの企画は不可 避と思われる。日本からもこれに関連した報告 者がでることになりそうである。

大会期間中に「若手研究者の時間」が設けら れていたが、ISPPは、組織をあげて、若い研究 者の育成に熱心である。地域を決めて、若手研 究者の研究会が行われている。若い研究者がこ の学会に参加しやすい環境整備をすることは、 日本の関連学会の責務である。

芹澤 功（せりざわ いさお 1932年生）

日本学術会議第2部会員、武蔵工業大学教育研究センタ 一教授、日本選挙学会前理事長

専門: 政治学 